\title{
Safety Evaluation of a Standardized Macleaya cordata Extract in a Ninety Day Feeding Study in Weaned Piglets
}

\author{
Lu Zhao $^{1 *}$, Sophie von Alvensleben ${ }^{2}$, Giorgio Fusconi' ${ }^{3}$, Mauro Morlacchini ${ }^{3}$ \\ ${ }^{1}$ Burdock Group, Orlando, FL, USA \\ ${ }^{2}$ Phytobiotics, Futterzusatzstoffe GmbH, Eltville, Germany \\ ${ }^{3}$ CERZOO Srl, Piacenza, Italy \\ Email: *lzhao@burdockgroup.com
}

How to cite this paper: Zhao, L., von Alvensleben, S., Fusconi, G. and Morlacchini, M. (2017) Safety Evaluation of a Standardized Macleaya cordata Extract in a Ninety Day Feeding Study in Weaned Piglets. Open Journal of Animal Sciences, 7, 213-231.

https://doi.org/10.4236/ojas.2017.72017

Received: March 31, 2017

Accepted: April 27, 2017

Published: April 30, 2017

Copyright () 2017 by authors and Scientific Research Publishing Inc. This work is licensed under the Creative Commons Attribution International License (CC BY 4.0).

http://creativecommons.org/licenses/by/4.0/

\begin{abstract}
The aim of this study was to assess the effects of Sangrovit ${ }^{\oplus}$, a standardized preparation of Macleaya cordata extract (MCE), on the health status and performance in weaned piglets. A total of 128 weaned piglets were randomly divided into four groups ( $n=32,16 / \mathrm{sex} /$ group $)$ and fed either a control feed (T1) or the control feed supplemented with $100 \mathrm{mg} / \mathrm{kg}$ (T2), $500 \mathrm{mg} / \mathrm{kg}$ (T3), or $1000 \mathrm{mg} / \mathrm{kg}$ (T4) Sangrovit ${ }^{\oplus}$ (resulting in $0,3.5,17.5,35 \mathrm{mg} \mathrm{MCE} / \mathrm{kg}$ feed, respectively) for ninety days. The parameters for growth and health status were evaluated during the trial and blood was collected on Day 0 and Day 91 for hematology and biochemistry analysis. After the animals were sacrificed, the weight of the major organs and tissues was measured and histopathological examination on the organs from 8 animals in each group (4/sex/group) was performed. The results showed no statistically significant differences in live weight, feed intake, and average daily weight gain between the treatment and control groups. The feed containing 100, 500, or $1000 \mathrm{mg} / \mathrm{kg}$ Sangrovit ${ }^{\circ}$ was well tolerated by piglets, with no adverse effects noted during the feeding period or in the histopathological results. The majority of the hematological and blood biochemistry parameters displayed no significant changes between the control and treatment groups. Compared to the control group, some hematological parameters including MCV, platelets concentration, and APTT were modified in some but not all treatment groups. Some significant changes in the blood biochemistry parameters were found in the treatment groups including levels in bile acid, haptoglobin, total serum protein, and GTT, as well as creatine kinase activity, but those changes were not toxicologically significant because no observed changes were seen in other similar biomarkers. In sum, this study demonstrated that the addition of Sangrovit ${ }^{\circ}$ to swine feed at up to $1000 \mathrm{mg} / \mathrm{kg}$ does not result in any toxicological effects to the health status and growth of weaned piglets.
\end{abstract}




\section{Keywords}

Macleaya cordata, Piglets, Sanguinarine, Tolerance

\section{Introduction}

Macleaya cordata ( $M$. cordata) is a deciduous perennial plant found across North America, Eastern Asia, and European countries. It is hollow-stemmed, leafy and fast growing and can grow to 2.0 meters high [1]. Previous studies have shown that the aerial parts of $M$. cordata contain a variety of quaternary benzophenanthridine alkaloids (QBAs) that display multiple biological activities. Isolation of QBA, though in impure form, was first reported in the first half of the 19 th century. Other forms of QBA have been discovered since then and in the mid-1980s approximately 80 naturally occurring compounds of this type were reported [2]. Long before pure alkaloids were isolated, plants of the Papaveraceae family containing QBAs such as sanguinarine and chelerythrine, including the plant Sanguinaria canadensis (blood root) that contains 4\% - 7\% QBA in rhizome and $1.8 \%$ in roots, Chelidonium majus (celandine) that contains $4.5 \%$ QBA in roots, and $M$. cordata that contains 3\% QBA in aerial parts, were utilized in traditional medicine in North America, Europe and China for analgesic, antiedemic, carminative, depurative, and diuretic properties [3].

Among the alkaloid varieties, sanguinarine and chelerythrine are colorless and crystalline substances that have been well investigated for their unique properties [1] [4]. Sanguinarine and chelerythrine are bitter in taste and products containing these substances have been used as natural appetizing agents to feed farm animals, such as swine [3], bovines [5], poultry [6] and fish [7]. Swine (Sus scrofa domesticus L.) is one of the most important commercial livestock species that provides more than one third of the meat production in the world [8]. Previous studies have found that the bitter taste is a part of the swine taste receptor system [9] and QBAs from M. cordata have been identified as flavoring compounds [10] which could potentially improve palatability of animal feed like some other phytogenic compounds [11]. In this study, M. cordata extract (MCE), a bitter tasting substance, is proposed to provide a consistent taste to the feed, and to mask subtle changes that may affect feed intake of piglets.

MCE has been included in the European Feed Additive Register and approved for use as a flavoring compound for farm animals. Sangrovit ${ }^{\circledast}$ is a standardized preparation of MCE, manufactured by an ethanol-based extraction of the aerial portions of the $M$. cordata plant, which contains 3.5\% MCE (providing 1.5\% sanguinarine). The recommended use rate for Sangrovit ${ }^{\circledR}$ to be added to premixes or to compound feed is $15-100 \mathrm{mg} / \mathrm{kg}$ in feed. Dietary supplementation with Sangrovit ${ }^{\oplus}$ has been demonstrated to elevate daily body weight gain and feed conversion ratio in chickens [12] [13] and optimize the nitrogen utilization and feed digestion in bovine [5] [14]. In swine, Sangrovit ${ }^{\circledR}$ has been evaluated for its effects on stress response and pathogen shedding in finishing pigs [15] and ef- 
fects on the growth parameters in weaning piglets [3]. However, few studies have been conducted to assess the safety of MCE consumption in weaned piglets. The objective of this study was to determine the tolerability and health status of consumption of Sangrovit ${ }^{\oplus}$, a standardized preparation of MCE that contains sanguinarine and chelerythrine as major active components, for 90 days by weaned piglets at the levels of 100, 500, $1000 \mathrm{mg}$ Sangrovit ${ }^{\circledast} / \mathrm{kg}$ feed.

\section{Materials and Methods}

\subsection{Test Substance}

A manufactured preparation of MCE, under the trade name of Sangrovit ${ }^{\bullet}$, was provided by Phytobiotics Futterzusatzstoffe GmbH (Eltville, Germany) and used as the test substance for all the experiments in this study. The Sangrovit ${ }^{\circledR}$ preparation was a reddish-orange-green colored granula that was standardized to contain at least $1.5 \%$ sanguinarine resulting in about 3.5\% MCE. The level of sanguinarine and chelerythrine in Sangrovit ${ }^{\circledR}$ in the feed were measured by validated methods as previously described [12]. No microbiological contamination such as Salmonella was detected after analysis, and heavy metal content was within limits set in the legislation of the European Union (Arsenic: $<2 \mathrm{mg} / \mathrm{kg}$; Mercury: <0.1 mg/kg; Cadmium: <1 mg/kg; Lead: $<10 \mathrm{mg} / \mathrm{kg}$ ).

\subsection{Experimental Animals and Diets}

This trial was carried out on 128 hybrid piglets (64 females and 64 castrated males; Bompieri $\times$ Goland genetic line that is a Large White $\times$ Duroc cross; sire line was the hybrid boar of the Bompieri line), weaned at approximately 28 days of age. The breeding farm code was 125 BS 001/6 and the farm was located in Pontevico (BS), Italy. The study was conducted in two compartments, i.e., weaning rooms and growing rooms, depending on the growth phase and weight of the animals at the CERZOO S.r.l. facility (Piacenza, Italy). The conditions were regarded as representative for a modern commercial operation in Europe. The total treatment duration was 90 days, plus an acclimatization period of 7 days before the study started. After the acclimatization period, the animals were weighed, selected for healthy individuals, and assigned to the control and treatment groups to achieve maximum possible homogeneity within each group and minimize differences between the groups. An average of live weight (LW) was $7.83( \pm 0.89) \mathrm{kg}$ when piglets entered the study on Day 0 (D0). Four piglets of the same gender were housed in one cage, with eight cages per treatment group (i.e., 16 castrated males and 16 females/group). For the first 42 days (D0 - D41) of the study, the animals were housed in the weaning rooms in flat-deck cages. For the remaining 48 days (D42 - D90) of the study, the animals were housed in the growing room on a slatted floor. The trial facility was equipped with a dynamic ventilation system that enabled the facility to control the ventilation rate according to the temperature and age of the pigs. The temperature $\left(27.1^{\circ} \mathrm{C} \pm\right.$ $\left.1.0^{\circ} \mathrm{C}\right)$ and relative humidity $(62.4 \% \pm 8.6 \%)$ in the weaning room and growing room were recorded every $30 \mathrm{~min}$. The temperature was automatically adjusted 
as necessary. Natural daylight was utilized as a light source during the whole trial period.

The weaned piglets were fed with typical corn-soybean meal-based basal diets in dry powder form, the compositions of which were changed to meet or exceed the nutrient requirements recommended for piglets in different growth stages (NRC 2012). The basal diets for three different experimental periods (one for each experimental period: D0 to D21, D21 to D42, D42 to D90) were prepared by Ferraroni S.r.l. Feed Mill (Bonemerse, CR, Italy) and formulated without antibiotics, antibiotic growth promoters (AGP), or AGP alternatives (Table 1). The experimental diets (T1, T2, T3, and T4 diets) for each growth period were prepared by mixing $0,100,500$, or $1000 \mathrm{mg}$ Sangrovit $/ \mathrm{kg}$ feed using the basal diets, and were mixed at the CERZOO Feed Mill (Piacenza, Italy); homogenous distribution of Sangrovit ${ }^{\oplus}$ was ensured by dietary analysis. Both control and test diets were analyzed for moisture, ash, starch, crude protein, crude fat and fiber, as well as the content of sanguinarine and chelerythrine. The sanguinarine and chelerythrine contents in the basal (T1) diet were under the analytical detection limit $(<0.01 \mathrm{mg} / \mathrm{kg}$ diet). The treatment diets were found to contain $1.68-1.75$ $\mathrm{mg}$ sanguinarine and $0.55-0.65 \mathrm{mg}$ chelerythrine per $\mathrm{kg}$ T2 diet, $8.42-8.60 \mathrm{mg}$ sanguinarine and 2.75 - $3.27 \mathrm{mg}$ chelerythrine per kg T3 diet, and $16.64-17.01$ $\mathrm{mg}$ sanguinarine and $5.52-6.83 \mathrm{mg}$ chelerythrine per $\mathrm{kg}$ T4 diet (Table 1). During the trial period, the animals were fed ad libitum using one steel feeder per cage. The drinking water was provided ad libitum by an internal water system in which the water quality was analyzed annually. Feed intakes were measured and recorded per cage on Day 0, 21, 42, and 90.

\subsection{Study Design}

Piglets were divided into four groups with equal sex distribution in each group. The minimum sample size to pick up differences in $1 \mathrm{~kg}$ live weight between each treatment was calculated and a sufficient sample size of $n=32$ was utilized for each group (16 castrated males and 16 females/group). The animals were fed with either a control diet (T1) or one of the three treatment diets supplemented with 100 (T2), 500 (T3) and 1000 (T4) mg Sangrovit $\% / \mathrm{kg}$ feed for ninety days. Daily inspections were carried out by qualified personnel while periodic inspections were made during the study by veterinarians and responsible staff of animal welfare. Individual LW of the piglets was recorded on Day 0, 21, 42 and 90. Average daily feed intake (ADFI) by cage was determined by the difference between the feed offered and the feed refused and calculated back for each growing period (i.e., Day 0 - 21, Day 21 - 42, Day 42 - 90) and for the complete study period (Day 0 - Day 90). Similarly, average daily gain (ADG), and feed: gain ratio (F:G) per cage were calculated by different growth periods. Blood samples were collected on D0 and D91 for hematology and biochemistry analysis. At the end of the study (D91), one animal of each cage (32 in total: 4 castrated males and 4 females for each treatment) was slaughtered, and the carcass was subjected to detailed gross necropsy. During necropsy, organs and tissue samples from all 
Table 1. Composition and analytical characteristics (as feed) of the basal diets in the 3 growing periods.

\begin{tabular}{|c|c|c|c|}
\hline Ingredient (\%) & $\begin{array}{l}\text { First Experimental Period } \\
\text { (D0 - D21) }\end{array}$ & $\begin{array}{l}\text { Second Experimental Period } \\
(\mathrm{D} 21-\mathrm{D} 42)^{3}\end{array}$ & $\begin{array}{l}\text { Third Experimental Period } \\
(\mathrm{D} 42-\mathrm{D} 90)^{3}\end{array}$ \\
\hline Corn meal & 41.00 & 46.75 & 59.48 \\
\hline Soybean meal $44 \%$ & 35.27 & 30.40 & 21.50 \\
\hline Wheat meal & 6.00 & 6.00 & 10.00 \\
\hline Milk whey & 6.00 & 6.00 & - \\
\hline Oil of plant origin & 3.90 & 3.50 & 2.20 \\
\hline Wheat bran & 3.00 & 3.00 & 3.00 \\
\hline Monocalcium phosphate & 1.10 & 1.00 & 1.00 \\
\hline Limestone & 1.25 & 1.10 & 1.20 \\
\hline Salt & 0.30 & 0.20 & 0.20 \\
\hline Sodium bicarbonate & 0.80 & 0.80 & 0.40 \\
\hline L-Lysine $\mathrm{HCl}$ 98\% & 0.60 & 0.60 & 0.44 \\
\hline DL-methionine & 0.25 & 0.20 & 0.15 \\
\hline L-Threonine & 0.23 & 0.18 & 0.16 \\
\hline L-Tryptophan & 0.05 & 0.02 & 0.02 \\
\hline Vitamins and minerals & 0.25 & 0.25 & 0.25 \\
\hline \multicolumn{4}{|l|}{ Analytical characteristics (\%) } \\
\hline Dry matter & 90.5 & 90.05 & 89.41 \\
\hline Crude protein & 20.80 & 18.59 & 16.56 \\
\hline Crude fat & 6.40 & 5.36 & 5.27 \\
\hline Crude fiber & 3.84 & 4.65 & 3.07 \\
\hline Ash & 6.40 & 5.96 & 4.60 \\
\hline Starch & 33.15 & 38.87 & 46.15 \\
\hline $\mathrm{DE}, \mathrm{kcal} / \mathrm{kg}^{1}$ & 3277 & 3262 & 3506 \\
\hline $\mathrm{NE}, \mathrm{kcal} / \mathrm{kg}^{2}$ & 2782 & 2781 & 2808 \\
\hline \multicolumn{4}{|c|}{ Sanguinarine in the diet $(\mathrm{mg} / \mathrm{kg})$} \\
\hline $\mathrm{T} 1$ & $<0.01$ & $<0.01$ & $<0.01^{4}$ \\
\hline $\mathrm{T} 2$ & $1.71 \pm 0.08$ & $1.75 \pm 0.03$ & $1.69 \pm 0.05^{4}$ \\
\hline $\mathrm{T} 3$ & $8.47 \pm 0.13$ & $8.85 \pm 0.46$ & $8.60 \pm 0.38^{4}$ \\
\hline $\mathrm{T} 4$ & $16.71 \pm 0.58$ & $17.17 \pm 0.60$ & $17.01 \pm 0.31^{4}$ \\
\hline \multicolumn{4}{|c|}{ Chelerythrine in the diet $(\mathrm{mg} / \mathrm{kg})$} \\
\hline $\mathrm{T} 1$ & $<0.01$ & $<0.01$ & $<0.01^{4}$ \\
\hline $\mathrm{T} 2$ & $0.55 \pm 0.03$ & $0.64 \pm 0.01$ & $0.65 \pm 0.16^{4}$ \\
\hline $\mathrm{T} 3$ & $2.75 \pm 0.04$ & $3.27 \pm 0.15$ & $3.24 \pm 0.12^{4}$ \\
\hline $\mathrm{T} 4$ & $5.52 \pm 0.18$ & $6.83 \pm 0.18$ & $6.33 \pm 0.16^{4}$ \\
\hline
\end{tabular}

${ }^{1} \mathrm{DE}=$ Digestible energy, was calculated according to the equation of Noblet and Perez [30]. ${ }^{2} \mathrm{NE}=$ Net energy, was calculated according to the equation of Noblet et al. [31]. ${ }^{3}$ There are no statistically difference in basal ingredient composition between control and treatment diets in 3 growing periods. The mean values of composition for the basal ingredient (expect sanguinarine and chelerythrine) in T1 diets were used and represented the basal composition for all the treatment groups. ${ }^{4}$ The data was obtained from first batch manufactured. The data from second batch were similar (not shown).

groups (T1, T2, T3, and T4) were preserved for histopathology evaluation. This study was conducted in full compliance with Good Laboratory Practice (GLP) 
guidelines under Italian Legislation (Directives 2004/9/CE and 2004/10/CE, according to Italian Legislation D.L. March 2, 2007, n.50).

\subsection{Diarrhea Scoring}

General health status of the animals was checked twice daily. Subjective diarrhea scores were recorded daily. Diarrhea scores on cage basis were determined based on the performance of individual pigs and signs of stool consistency in the cage, ranging from $1-3$ ( 1 = well-formed feces; 2 = sloppy feces; $3=$ diarrhea) [16] [17].

\subsection{Blood Biochemistry and Hematological Analysis}

Blood collections were conducted at the beginning and the end of the trial. On Day 0 (before the trial started), blood was collected from 20 randomly-selected piglets (10 females and 10 castrated males). On Day 91, blood was collected from one randomly selected animal from each cage (32 piglets in total, 4 females and 4 castrated males for each treatment). Blood samples were drawn by aorta vein puncture using disposable Becton Dickinson Acute Care (U.S.A.) syringes and collected into three types of $10 \mathrm{ml}$ vacuum tubes: 1) containing lithium heparin as anticoagulant; 2) containing sodium citrate as anticoagulant; and 3) containing no anticoagulant. The samples were immediately dispatched to the laboratory for analysis at $4^{\circ} \mathrm{C}$. The blood samples treated with lithium heparin were used as whole blood to measure the hematological parameters including erythrocytes (RBCs) total counts, leukocytes (WBC) total and differential counts, packed cell volume (PCV), mean corpuscular volume (MCV), mean corpuscular hemoglobin $(\mathrm{MCH})$ and mean corpuscular hemoglobin concentration (MCHC), platelet count, red blood cell distribution width (RDW). Plasma was obtained by centrifuging the blood samples treated with sodium citrate at $3500 \mathrm{rpm}$ for $10 \mathrm{~min}$ at $4^{\circ} \mathrm{C}$ and used to analyze for fibrinogen, prothrombin time, and activated partial thromboplastin time. Serum was obtained by clotting the blood sample at room temperature and centrifuging the blood samples without anticoagulant treatment at $3500 \mathrm{rpm}$ for $10 \mathrm{~min}$ at $4^{\circ} \mathrm{C}$ and were used to analyze the biochemical parameters, including sodium, urea nitrogen, potassium, creatinine, chloride, alanine aminotransferase (GPT/ALT), calcium, aspartate aminotransferase (GOT/AST), phosphate, lactate dehydrogenase (LDH), magnesium, gammaglutamyltransferase (GGT), total protein, alkaline phosphatase (AP), albumin, creatine kinase (CK), globulin, total bile acids, glucose, cholesterol, amylase, acute phase protein (haptoglobin, and ceruloplasmin) and the four categories of globulin ( $\alpha 1, \alpha 2, \beta$, and $\gamma$ globulin). Blood biochemistry and hematological analyses were performed by La Fontana laboratory (Piacenza, Italy) which was certified with ISO 90001-2008 (certificate n. 18734/08/S).

\subsection{Veterinary Necropsy and Histopathology Examination}

At the end of the study (Day 91), 32 experimental animals (8 animals/treatment; the same animals used for the blood collection) were necropsied by a veterinary 
surgeon at CERZOO. A gross examination was carried out on the organs and tissues, which included a gross check on: pituitary gland, brain, bone and marrow, kidneys, thyroid gland, spinal cord, marrow smear, caecum, eyes, spleen, urinary bladder, adrenal gland, lung, stomach, thymus, pancreas, muscle, duodenum, heart, ovaries (for females), mammary gland (for female), jejunum, lymph nodes, uterus (for female), liver, ileum, skin, gall bladder, colon. The organs and tissues of 16 animals ( 8 animals ( 4 animals/sex) from T1 group, 8 animals ( 4 animals/sex) from T4 group) were collected and examined for histopathology by the designated veterinarian for animal welfare. The histopathological examination covered the organs and tissues that include: adrenal glands, aorta, bone (sternum, femur including articular surface), bone marrow (sternum, femur), brain (including sections of forebrain, upper brain stem, mid brain, medulla oblongata, pons, cerebral and cerebellar cortex), esophagus, eyes with retina and optic nerve, female and male mammary gland area, gallbladder, heart, kidneys, lacrimal gland, larynx, liver, lungs, lymph nodes (retropharyngeal, mesenteric), nasal cavity (including turbinates and paranasal sinuses), nictitating gland (for Harderian gland), olfactory bulb, oro-nasal pharynx (adjacent to hard palate), ovaries (female only), oviducts, pancreas, Peyer's patches, pituitary gland, salivary glands, sciatic nerve, skeletal muscle, skin and subcutaneous tissue, small intestine (duodenum, jejunum, ileum), spinal cord (cervical (C1), mid-thoracic (T7), and lumbar (L7) segments including roots and dorsal root ganglia at lumbar level), spleen, stomach, thymus, thyroid gland, tongue, trachea, ureter, urethra, urinary bladder, uterus with cervix, vagina (for female). The samples were fixed in $10 \%$ buffered formalin or in modified Davidson's solution depending the type of organs and tissues sampled. The slide preparation and histopathology were conducted by AnaPath GmbH laboratory (Oberbuchsiten, Switzerland) in compliance with the Swiss Ordinance related to Good Laboratory Practice [SR 813.112.1]. Histological sections of tissues were trimmed, embedded, sectioned, stained with hematoxylin and eosin (further stains if needed), and examined by the study pathologist. To elucidate the nature of an individual animal's tissue changes, tissue sectioning, staining and microscopic examination was conducted as requested by the study pathologist.

\subsection{Statistical Analysis}

Data obtained in this experiment were analyzed by using the software program of SAS 2002-2010, Release 9.3 (Cary, NC, USA) under the General Linear Model (GLM) procedure. Analysis of Variance (ANOVA) was used as the main statistical test and the Student's t and Tukey's tests were used to compare the means from each group. Treatment effect for animals in both sex and treatment $\times$ sex interaction were calculated by ANOVA. A statistical analysis by each sex were also conducted. $P \leq 0.05$ in the ANOVA model was considered as statistically significant. The raw data were analyzed for outliers, and no data were excluded. The data of fecal score were tested for normal distribution and analyzed as repeated measurements in a completely randomized design using the MIXED 
procedure of SAS 2002-2010, Release 9.3.

\section{Results and Discussion}

During the study period, the general health status of piglets was normal with no mortality and morbidity observed in different treatment groups. The fecal scoring results didn't show any statistically significant differences between control and treatment groups (all $P>0.05$, Table 2). The LW and ADFI for the weaned piglets during three growing stages (D0 - D21, D21 - D42 and D42 - D90) and the whole 90-day trial period (D0 - D90) are shown in Table 3. There were no significant differences in LW between the control (T1) and treatment groups (T2, T3, T4 group, fed with 100, 500, $1000 \mathrm{mg}$ Sangrovit ${ }^{\circledast} / \mathrm{kg}$ feed) during the three growing stages (treatment effect $P>0.05$ for both sex). Additionally, no statistically significant differences were observed among different feeding groups (treatment effect $P>0.05$ for both sex) in ADG,ADFI, and F:G over different growth stages and the whole 90 -day trial period. It is noted that there was a statistically significant treatment $\times$ sex interaction in ADFI for the whole study period $(P=0.0305)$, but the interaction was not observed in other performance parameters (all $P>0.05$ ). A statistical analysis by each sex was conducted and no statistically significant differences were found in ADFI in separated sex. The results are in agreement with previous findings in which 21-day-old hybrid piglets fed a basal feed supplemented with $2 \mathrm{mg}$ MCE (containing $1.28 \mathrm{mg}$ sanguinarine and $0.44 \mathrm{mg}$ chelerythrine)/kg feed and $100 \mathrm{mg}$ MCE (containing $64.03 \mathrm{mg}$ sanguinarine and $21.99 \mathrm{mg}$ chelerythrine)/kg feed for 90 days displayed growth characteristics (e.g., feed conversion efficiency) very similar to the corresponding control piglets [18]. However, Kantas et al. [3] found that supplementation of $50 \mathrm{mg} / \mathrm{kg}$ Sangrovit ${ }^{\circledR}$ (containing $0.75 \mathrm{mg} / \mathrm{kg}$ sanguinarine) in the feed significantly increased feed consumption and feed conversion ratio in six-week-old piglets, which is not observed in this study. The discrepancy between different studies may be attributed to different sample size, difficulty in showing significant growth changes in short period or growth variation in different swine breeds, as Jeroch et al. [19] reported that Sangrovit ${ }^{\circledR}$ exerted a significant effect on performance results (body weight gain, feed conversion ratio) in two out of four experiment conducted on different swine breeds, but there were no effects

Table 2. Fecal score in female and castrated male piglets.

\begin{tabular}{|c|c|c|c|c|c|c|c|c|c|}
\hline \multirow{2}{*}{ Trial periods } & \multicolumn{2}{|c|}{ T1 Control } & \multicolumn{2}{|c|}{ T2 $100 \mathrm{mg} / \mathrm{kg}$ Sangrovit ${ }^{\bullet}$} & \multicolumn{2}{|c|}{ T3 500 mg/kg Sangrovit ${ }^{\circ}$} & \multicolumn{2}{|c|}{ T4 $1000 \mathrm{mg} / \mathrm{kg}$ Sangrovit ${ }^{\bullet}$} & \multirow{2}{*}{ Treatment effect $(P=)$} \\
\hline & F & $\mathrm{CM}$ & F & $\mathrm{CM}$ & $\mathrm{F}$ & $\mathrm{CM}$ & F & $\mathrm{CM}$ & \\
\hline D0 - D21 & $1.54 \pm 0.50$ & $1.50 \pm 0.53$ & $1.54 \pm 0.50$ & $1.37 \pm 0.49$ & $1.55 \pm 0.50$ & $1.43 \pm 0.50$ & $1.55 \pm 0.52$ & $1.48 \pm 0.50$ & 0.9116 \\
\hline D21 - D42 & $1.48 \pm 0.50$ & $1.57 \pm 0.52$ & $1.36 \pm 0.48$ & $1.51 \pm 0.53$ & $1.52 \pm 0.50$ & $1.35 \pm 0.48$ & $1.36 \pm 0.48$ & $1.52 \pm 0.50$ & 0.5170 \\
\hline D42 - D90 & $1.46 \pm 0.51$ & $1.52 \pm 0.51$ & $1.39 \pm 0.49$ & $1.48 \pm 0.50$ & $1.38 \pm 0.50$ & $1.48 \pm 0.50$ & $1.38 \pm 0.49$ & $1.48 \pm 0.52$ & 0.8502 \\
\hline D0 - D90 & $1.48 \pm 0.51$ & $1.53 \pm 0.52$ & $1.42 \pm 0.49$ & $1.46 \pm 0.50$ & $1.45 \pm 0.50$ & $1.44 \pm 0.50$ & $1.41 \pm 0.50$ & $1.49 \pm 0.51$ & 0.6922 \\
\hline
\end{tabular}

Score: 1 = well-formed feces, 2 = sloppy feces, 3 = diarrhea. The statistic comparisons were conducted between control and treatment groups for the animals in the same gender (female vs. female, castrated male vs. castrated male). $\mathrm{F}=$ female piglets, $\mathrm{CM}=$ castrated male piglets, $\mathrm{n}=16 /$ sex in each group. Treatment effects was calculated for animals in both sex $(\mathrm{n}=32)$. No statistical differences were found between different groups (all $P>0.05)$. 


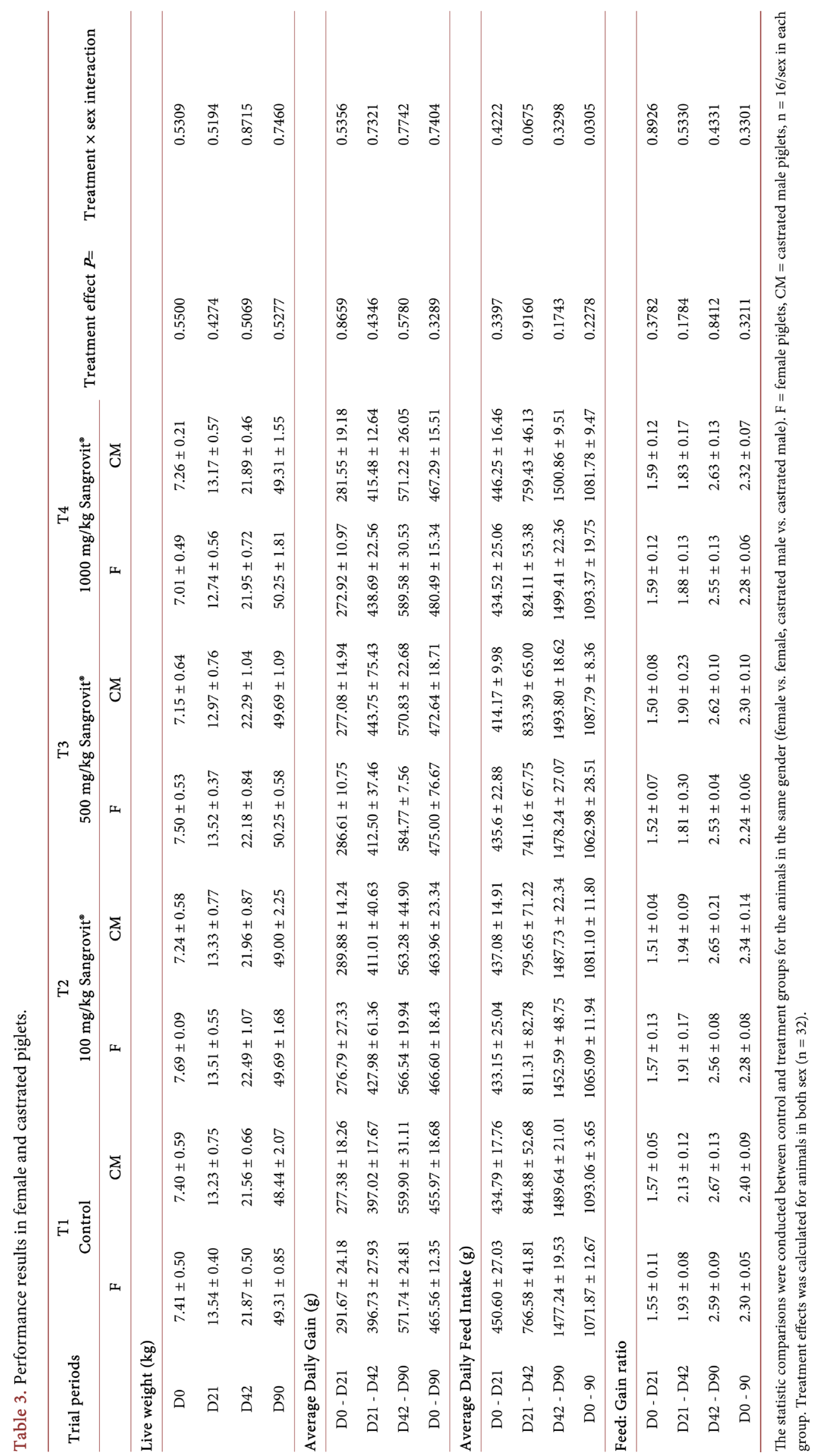


on growth performance in the other two experiments. Further studies are needed to evaluate the effects of Sangrovit ${ }^{\circledR}$ on growth performance in different swine breeds and the effectiveness for pigs at different growth stages.

During the 90 days of this experiment, all animals remained apparently healthy and manifested no signs of toxicity. The results of the hematology on D91 were summarized in Table 4. The majority of the parameters displayed no significant changes between the control and treatment groups. Some hematological parameters were statistically different between treatments, including $\mathrm{MCV}, \mathrm{MCH}$, platelets (treatment effect $P<0.05$ for all animals). As there were statistically significant (treatment $\times$ sex) interactions for MCV and platelets $(P<$ 0.05), a statistical analysis for each sex was conducted and the comparison was presented by sex as below. For the female piglets, the mean corpuscular volume (MCV) was statistically significantly higher in the T2 and T3 groups (100 and $500 \mathrm{mg} / \mathrm{kg}$ Sangrovit ${ }^{\circledR}$ in feed) than those in the T1 (control) group. The platelet concentration in the T3 and T4 group (500 and $1000 \mathrm{mg} / \mathrm{kg}$ Sangrovit ${ }^{\oplus}$ in feed) were significantly lower relative to those in the T1 (control) group. For the castrated male piglets, the active partial thromboplastin time (APTT) in the T2 group was significantly lower than those in the T1 group. For the MCV changes in female piglets and APTT discrepancy in castrated male piglets, these responses were only shown in some (T2 or T3) groups but not in the other treatments (T3 and/or T4), which were not dose-dependent. Therefore, the differences in MCV and APTT were not test article related and were attributed to biological variation as the results are sporadic and not dose dependent. Platelets are a component of blood whose function is to interact with other coagulation factors and stop bleeding by clumping and clotting blood vessel injuries. Low platelet concentration was used as an indicator for thrombocytopenia and can be attributed to a decrease in platelet production or an increase in platelet destruction [20]. In this study, the low platelet count occurred in the T3 and T4 group of female piglets was not toxicological relevant as the other biomarkers for thrombocytopenia and platelet function were unchanged between groups (e.g., APTT and prothrombin time (PT) that are important measures for blood clotting did not altered) and no signs of bleeding and tissue damage were observed in the treatment groups. In addition, the variations in platelet count were similar to the fluctuation in control or pre-study values, and were of a magnitude of change commonly observed in weaned piglets under similar study conditions [21].

The results of blood biochemistry analysis in the serum on D91 were summarized in Table 5. There were no statistically significant treatment effect for majority of the parameters. However, some blood biochemistry parameters were statistically significant different between treatments, including bile acids, haptoglobin, cholesterol, creatinine kinase (CK), gamma glutamyltransferase (GGT), potassium, and total protein (treatment effect $P<0.05$ for all animals). Due to treatment $\times$ sex interactions $(P<0.05)$, blood biochemistry parameters were also compared for each sex and the data were presented by sex as below. 


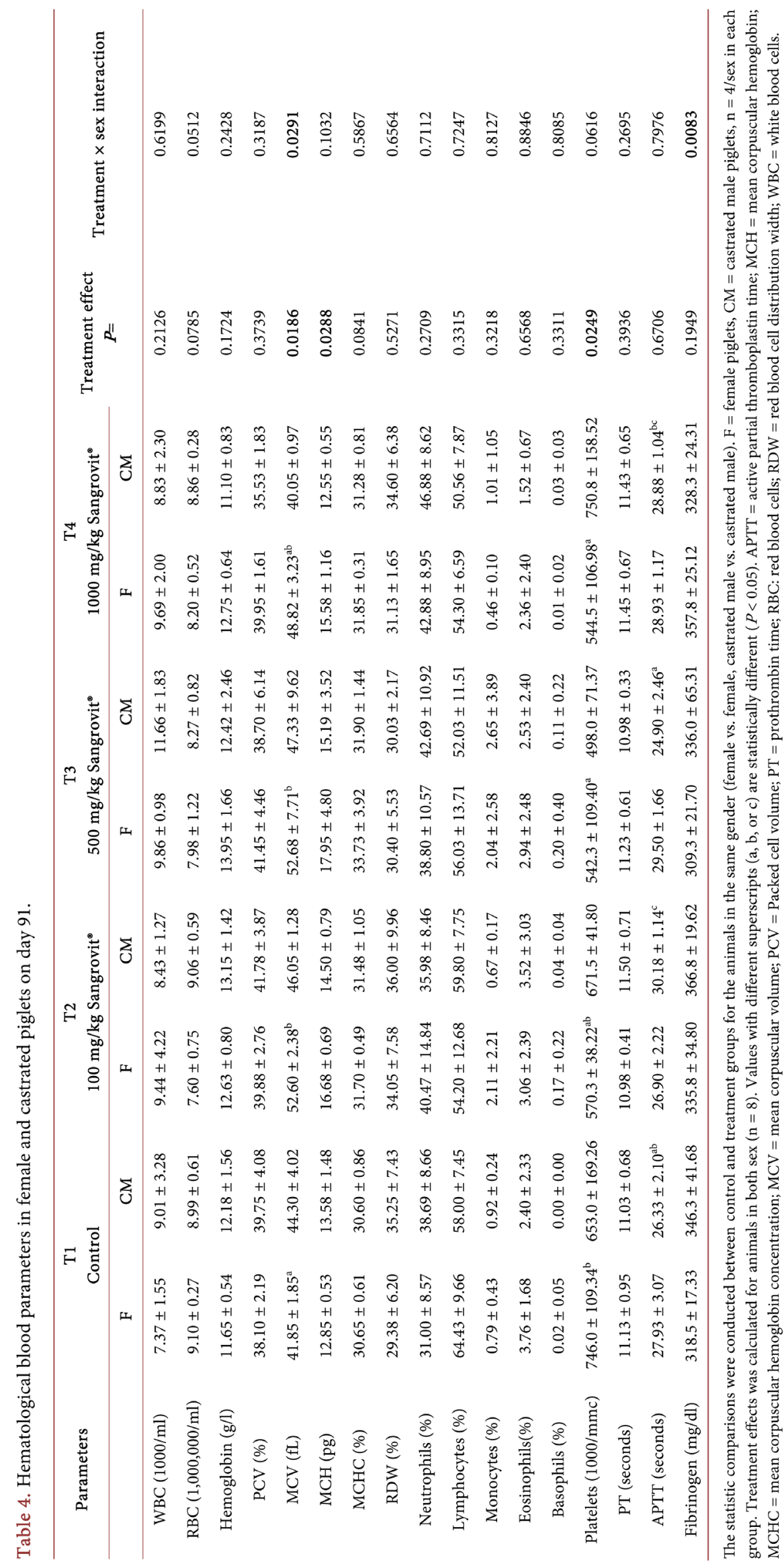




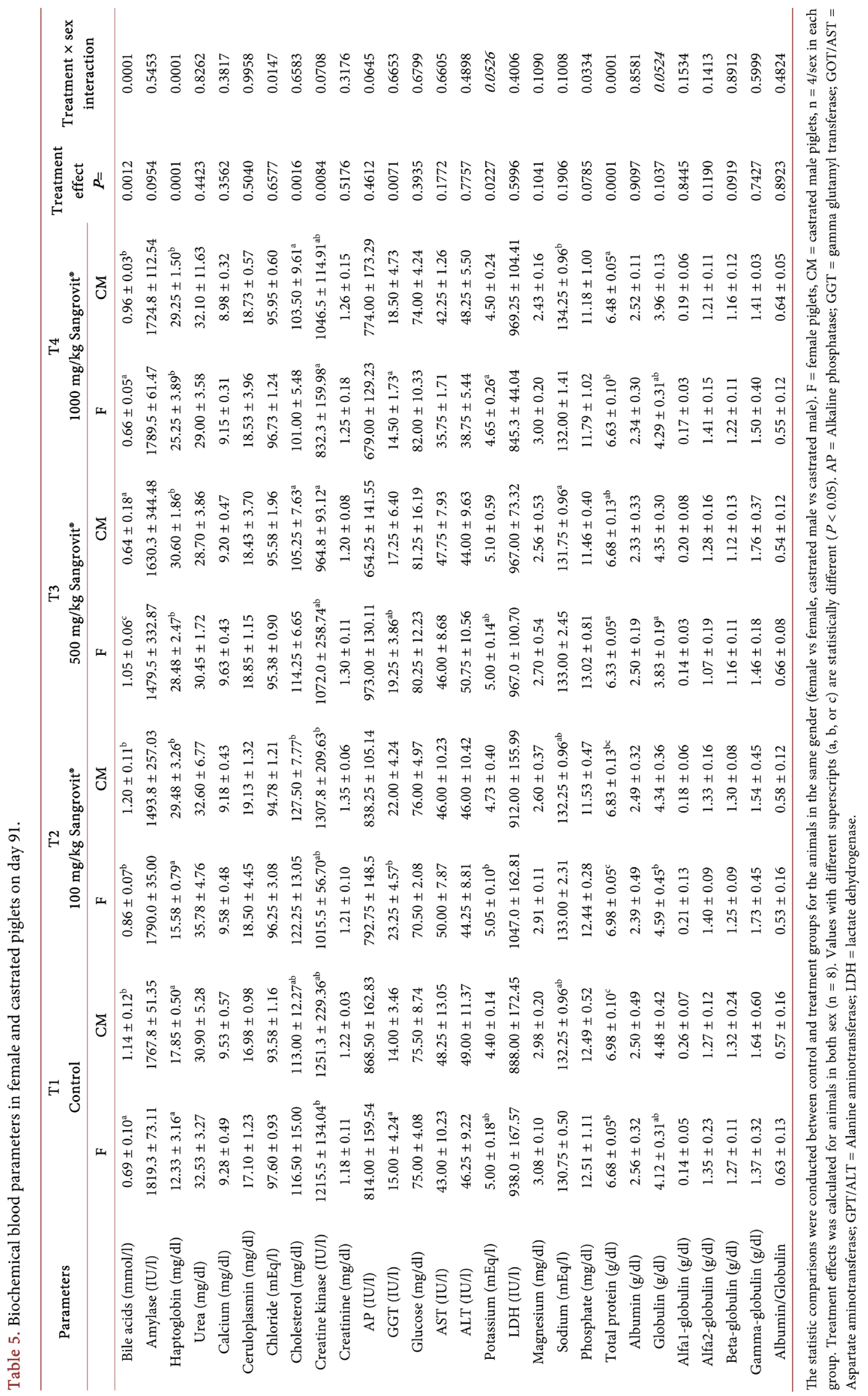


For female piglets, the bile acid concentration was significantly higher in the T2 and $\mathrm{T} 3$ groups, but was significantly lower for the castrated male piglets in the T3 group compared to those in the T1 group. These changes were only shown in the T2 or T3 groups but not in the other treatment (T4) group, which were not considered dose-dependent reactions. The haptoglobin level (a measure of the hemolysis) was minimally but statistically increased in all treatment groups (T2, $\mathrm{T} 3$ and T4) of castrated male piglets and in the T3 and T4 groups of female piglets compared to those in the T1 group. Haptoglobins are a family of hemoglobin binding proteins. A decrease in haptoglobin level was often linked to hemolytic anemia, while an increase in haptoglobin level can be attributed to inflammatory diseases or physiological changes such as acute stress [22] [23]. In this study, the increase in haptoglobin level in the treatment group did not correlate with alterations in inflammatory markers (e.g., white blood cell counts did not increase) [24] and no signs of inflammatory responses or tissue damage were observed in the animals; therefore, the variation in haptoglobin measurements is not toxicologically relevant. The total serum protein levels for castrated male piglets in the T3 and T4 group were found to be significantly lower than those in the $\mathrm{T} 1$ group; for female piglets, total protein level was increased in $\mathrm{T} 2$ group but decreased in T3 group. These variations in total protein level were consistent with the findings in other studies and considered as within normal range in weanling piglets [25]. In addition, other parameters of serum proteins such as serum albumin, and globulin levels did not change and no adverse effects or clinical signs were observed. Therefore, the changes in total protein level were not considered as a toxicologically relevant effect. Notably, lower creatine kinase (CK) activity was found in the T4 group of female piglets versus the control. Previous studies have shown that CK activity in pigs may be affected by many factors such as stress and stocking density [26]. In general, an increase in CK activity indicates muscle damage, while a decrease has been known to occur from muscle wasting [27]. However, the T4 group did not have a significant decrease in body weights, and CK levels did not correlate with serum creatinine levels. Therefore, the decrease in CK level in the T4 group was not toxicologically relevant. The remaining differences in blood biochemistry parameters, some of which attained statistical significance (e.g., GGT level for the female piglets in the T2 group was increased), were sporadic and not dose dependent and not test article related. It is noted that the blood hematological and biochemistry values differed as the piglets grew up (by comparing the values between D0 and D90). This finding is consistent with the results from other studies showing that blood hematological and biochemistry values changed in the pigs as their ages increased [28] [29] [30] [31].

After the piglets were slaughtered, the gross morphology of the piglets' organ and the organ weights were evaluated. As shown in Table 6, the gross examination of skin, brain, eyes, gastrointestinal tract (stomach, duodenum, jejunum, ileum, colon and caecum), major organs (pancreas, spleen, liver/gall bladder, kidneys, heart and lungs etc.), and tissue (muscle) did not reveal any pathological 
Table 6. Necropsy results in female and castrated male piglets.

\begin{tabular}{|c|c|c|c|c|c|c|c|c|c|}
\hline \multirow[t]{2}{*}{ Organ/Tissue } & \multicolumn{2}{|c|}{$\begin{array}{c}\mathrm{T} 1 \\
\text { Control }\end{array}$} & \multicolumn{2}{|c|}{$\begin{array}{c}\text { T2 } \\
100 \mathrm{mg} / \mathrm{kg} \text { Sangrovit }\end{array}$} & \multicolumn{2}{|c|}{$\begin{array}{c}\text { T3 } \\
500 \mathrm{mg} / \mathrm{kg} \text { Sangrovit }\end{array}$} & \multicolumn{2}{|c|}{$\begin{array}{c}\mathrm{T} 4 \\
1000 \mathrm{mg} / \mathrm{kg} \text { Sangrovit }\end{array}$} & \multirow[t]{2}{*}{ Treatment effect $P=$} \\
\hline & $\mathbf{F}$ & $\mathrm{CM}$ & $\mathbf{F}$ & $\mathrm{CM}$ & $\mathrm{F}$ & $\mathrm{CM}$ & $\mathbf{F}$ & $\mathrm{CM}$ & \\
\hline Skin & $0.50 \pm 0.58$ & $1.00 \pm 0.00$ & $0.50 \pm 0.58$ & $0.50 \pm 0.58$ & $0.50 \pm 0.58$ & $0.75 \pm 0.50$ & $0.25 \pm 0.50$ & $1.00 \pm 0.00$ & 0.8095 \\
\hline Brain & $0.00 \pm 0.00$ & $0.25 \pm 0.50$ & $0.25 \pm 0.50$ & $0.00 \pm 0.00$ & $0.25 \pm 0.50$ & $0.00 \pm 0.00$ & $0.00 \pm 0.00$ & $0.25 \pm 0.50$ & 1.0000 \\
\hline Eyes & $0.00 \pm 0.00$ & $0.25 \pm 0.50$ & $0.75 \pm 0.96$ & $0.25 \pm 0.50$ & $0.50 \pm 0.58$ & $0.50 \pm 0.58$ & $0.50 \pm 0.58$ & $0.25 \pm 0.50$ & 0.5044 \\
\hline Pituitary gland & $0.50 \pm 0.58$ & $0.00 \pm 0.00$ & $0.25 \pm 0.50$ & $0.25 \pm 0.50$ & $0.00 \pm 0.00$ & $0.25 \pm 0.50$ & $0.25 \pm 0.50$ & $0.00 \pm 0.00$ & 0.8637 \\
\hline Thyroid gland & $0.25 \pm 0.50$ & $0.25 \pm 0.50$ & $0.00 \pm 0.00$ & $0.50 \pm 0.58$ & $0.00 \pm 0.00$ & $0.50 \pm 0.58$ & $0.25 \pm 0.50$ & $0.50 \pm 0.58$ & 0.9369 \\
\hline Parathyroid gland & $0.50 \pm 0.58$ & $0.25 \pm 0.50$ & $0.25 \pm 0.50$ & $0.00 \pm 0.00$ & $0.25 \pm 0.50$ & $0.00 \pm 0.00$ & $0.25 \pm 0.50$ & $0.00 \pm 0.00$ & 0.5163 \\
\hline Heart & $0.25 \pm 0.50$ & $0.00 \pm 0.00$ & $0.25 \pm 0.50$ & $0.00 \pm 0.00$ & $0.00 \pm 0.00$ & $0.00 \pm 0.00$ & $0.00 \pm 0.00$ & $0.50 \pm 0.58$ & 0.5496 \\
\hline Lung & $0.50 \pm 0.58$ & $0.75 \pm 0.96$ & $0.75 \pm 0.96$ & $0.50 \pm 0.58$ & $0.50 \pm 0.58$ & $0.25 \pm 0.50$ & $0.50 \pm 0.58$ & $0.50 \pm 0.58$ & 0.8013 \\
\hline Spinal cord & $0.25 \pm 0.50$ & $0.25 \pm 0.50$ & $0.50 \pm 0.58$ & $0.25 \pm 0.50$ & $0.50 \pm 0.58$ & $0.00 \pm 0.00$ & $0.25 \pm 0.50$ & $0.25 \pm 0.50$ & 0.9369 \\
\hline Stomach & $0.25 \pm 0.50$ & $0.50 \pm 0.58$ & $0.50 \pm 0.58$ & $0.00 \pm 0.00$ & $0.25 \pm 0.50$ & $0.25 \pm 0.50$ & $0.25 \pm 0.50$ & $0.25 \pm 0.50$ & 0.9369 \\
\hline Liver & $0.75 \pm 0.96$ & $0.50 \pm 0.58$ & $0.25 \pm 0.50$ & $1.00 \pm 0.00$ & $0.50 \pm 0.58$ & $0.50 \pm 0.58$ & $0.75 \pm 0.96$ & $0.50 \pm 0.58$ & 0.9507 \\
\hline Gall bladder & $0.25 \pm 0.50$ & $0.50 \pm 0.58$ & $0.50 \pm 0.58$ & $0.50 \pm 0.58$ & $0.25 \pm 0.50$ & $0.25 \pm 0.50$ & $0.25 \pm 0.50$ & $0.25 \pm 0.50$ & 0.7079 \\
\hline Lymph nodes & $0.50 \pm 0.58$ & $0.00 \pm 0.00$ & $0.25 \pm 0.50$ & $0.25 \pm 0.50$ & $0.50 \pm 0.58$ & $0.25 \pm 0.50$ & $0.00 \pm 0.00$ & $0.50 \pm 0.58$ & 0.9369 \\
\hline Spleen & $0.00 \pm 0.00$ & $0.25 \pm 0.50$ & $0.50 \pm 0.58$ & $0.75 \pm 0.96$ & $0.25 \pm 0.50$ & $0.50 \pm 0.58$ & $0.50 \pm 0.58$ & $0.25 \pm 0.50$ & 0.3664 \\
\hline Pancreas & $0.00 \pm 0.00$ & $0.25 \pm 0.50$ & $0.25 \pm 0.50$ & $0.50 \pm 0.58$ & $0.00 \pm 0.00$ & $0.25 \pm 0.50$ & $0.25 \pm 0.50$ & $0.25 \pm 0.50$ & 0.9369 \\
\hline Kidneys & $0.00 \pm 0.00$ & $0.50 \pm 0.58$ & $0.50 \pm 0.58$ & $0.00 \pm 0.00$ & $0.00 \pm 0.00$ & $0.00 \pm 0.00$ & $0.00 \pm 0.00$ & $0.00 \pm 0.00$ & 0.4376 \\
\hline Adrenal gland & $0.25 \pm 0.50$ & $0.25 \pm 0.50$ & $0.50 \pm 0.58$ & $0.00 \pm 0.00$ & $0.25 \pm 0.50$ & $0.25 \pm 0.50$ & $0.00 \pm 0.00$ & $0.75 \pm 0.96$ & 0.9369 \\
\hline Bone and marrow & $0.25 \pm 0.50$ & $0.00 \pm 0.00$ & $0.00 \pm 0.00$ & $0.25 \pm 0.50$ & $0.00 \pm 0.00$ & $0.50 \pm 0.58$ & $0.00 \pm 0.00$ & $0.25 \pm 0.50$ & 0.8871 \\
\hline Marrow smear & $0.50 \pm 0.58$ & $0.25 \pm 0.50$ & $0.25 \pm 0.50$ & $0.00 \pm 0.00$ & $0.00 \pm 0.00$ & $0.00 \pm 0.00$ & $0.25 \pm 0.50$ & $0.00 \pm 0.00$ & 0.2288 \\
\hline Duodenum & $0.25 \pm 0.50$ & $0.50 \pm 0.58$ & $0.50 \pm 0.58$ & $0.00 \pm 0.00$ & $0.25 \pm 0.50$ & $0.25 \pm 0.50$ & $0.25 \pm 0.50$ & $0.25 \pm 0.50$ & 0.3664 \\
\hline Jejunum & $0.50 \pm 0.58$ & $0.25 \pm 0.50$ & $0.25 \pm 0.50$ & $0.50 \pm 0.58$ & $0.25 \pm 0.50$ & $0.25 \pm 0.50$ & $0.75 \pm 0.96$ & $0.00 \pm 0.00$ & 0.9459 \\
\hline Ileum & $0.50 \pm 0.58$ & $0.75 \pm 0.96$ & $0.75 \pm 0.96$ & $0.25 \pm 0.50$ & $0.50 \pm 0.58$ & $0.25 \pm 0.50$ & $0.25 \pm 0.50$ & $0.50 \pm 0.58$ & 0.7395 \\
\hline Colon & $0.00 \pm 0.00$ & $0.25 \pm 0.50$ & $0.00 \pm 0.00$ & $0.25 \pm 0.50$ & $0.00 \pm 0.00$ & $0.25 \pm 0.50$ & $0.00 \pm 0.00$ & $0.00 \pm 0.00$ & 0.8013 \\
\hline Caecum & $0.00 \pm 0.00$ & $0.25 \pm 0.50$ & $0.50 \pm 0.58$ & $0.75 \pm 0.96$ & $0.25 \pm 0.50$ & $0.50 \pm 0.58$ & $0.50 \pm 0.58$ & $0.25 \pm 0.50$ & 0.9459 \\
\hline Thymus & $0.25 \pm 0.50$ & $0.25 \pm 0.50$ & $0.75 \pm 0.96$ & $0.25 \pm 0.50$ & $0.75 \pm 0.96$ & $0.25 \pm 0.50$ & $0.00 \pm 0.00$ & $0.50 \pm 0.58$ & 0.5796 \\
\hline Muscle & $0.75 \pm 0.96$ & $0.75 \pm 0.96$ & $0.50 \pm 0.58$ & $0.50 \pm 0.58$ & $1.00 \pm 0.00$ & $0.75 \pm 0.96$ & $0.50 \pm 0.58$ & $0.75 \pm 0.96$ & 0.4376 \\
\hline Urinary bladder & $0.00 \pm 0.00$ & $0.50 \pm 0.58$ & $0.25 \pm 0.50$ & $0.25 \pm 0.50$ & $0.00 \pm 0.00$ & $0.00 \pm 0.00$ & $0.25 \pm 0.50$ & $0.00 \pm 0.00$ & 0.6549 \\
\hline Ovaries & $0.75 \pm 0.96$ & $-{ }^{1}$ & $0.25 \pm 0.50$ & - & $0.75 \pm 0.96$ & - & $0.75 \pm 0.96$ & - & 0.4262 \\
\hline Uterus & $0.50 \pm 0.58$ & - & $0.50 \pm 0.58$ & - & $0.50 \pm 0.58$ & - & $0.75 \pm 0.96$ & - & 0.8944 \\
\hline Mammary gland & $0.50 \pm 0.58$ & $0.00 \pm 0.00$ & $0.25 \pm 0.50$ & $0.25 \pm 0.50$ & $0.00 \pm 0.00$ & $0.25 \pm 0.50$ & $0.25 \pm 0.50$ & $0.00 \pm 0.00$ & 0.6695 \\
\hline
\end{tabular}

${ }^{1}$-, not available. The statistic comparisons were conducted between control and treatment groups for the animals in the same gender (female vs. female, castrated male vs. castrated male). $\mathrm{F}=$ female piglets, $\mathrm{CM}=$ castrated male piglets, $\mathrm{n}=4 / \mathrm{sex}$ in each group. Treatment effects was calculated for animals in both sex $(\mathrm{n}=32)$. Score: $0=$ no alteration found; $1=$ slight alterations; $2=$ alteration of medium intensity. No statistical differences were found between different groups (all $P>0.05$ ).

alterations in the control and MCE-fed animals with all the scores less than 1 (score 0 means no change; score 1 means slight alteration) and all $p$-values greater than 0.05 between the groups. The organ weights and their percentage to LW of male and female sacrificed piglet were measured (Table 7) and no statistically significant differences were found between the treatment and control 


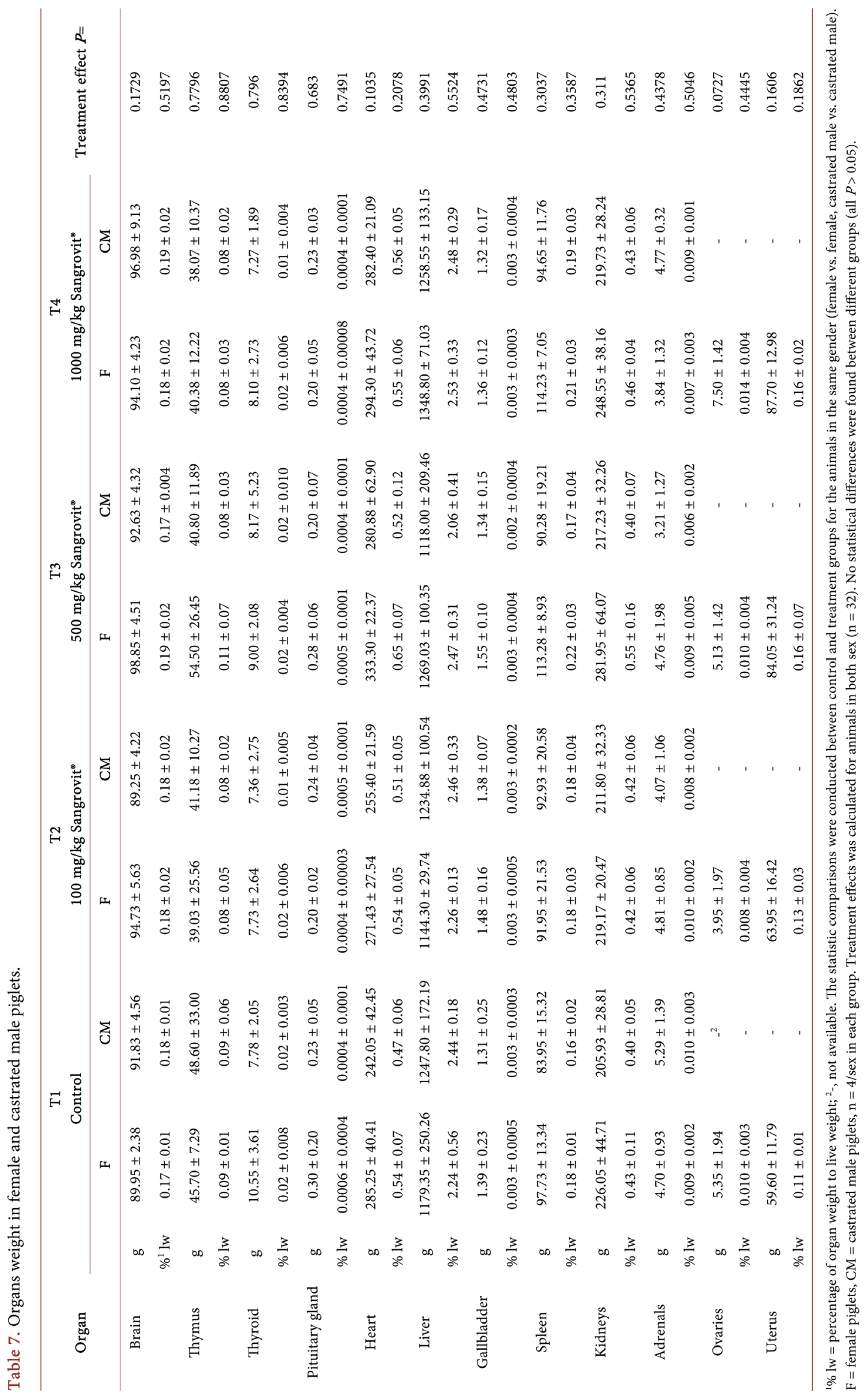


groups (all $P>0.05$ ). Furthermore, a comprehensive histopathological examination was performed on the organs and tissues from animals in the T4 (1000 $\mathrm{mg} / \mathrm{kg}$ Sangrovit ${ }^{\circledast}$ in feed) group and the T1 (control) group. Under the conditions of this study, histopathological examination didn't show the presence of any toxicity indicators in the tissues and organs examined.

MCE has been used as feed additive in animal feed for many years in Europe. Previous studies in swine and other animal species have shown that MCE consumption does not alter the hematology, histology or clinical chemistry parameters [3] [12] [18]. Kosina et al. showed in a 90-day feeding study that daily administration of $100 \mathrm{mg} / \mathrm{kg}$ MCE (extracted by the authors and contains 64.03 $\mathrm{mg} / \mathrm{kg}$ sanguinary and $21.99 \mathrm{mg} / \mathrm{kg}$ chelerythrine in feed) was safe to the young piglets [18]. The current study found a dosage of $35 \mathrm{mg} / \mathrm{kg}$ (or lower) MCE does not have any adverse effects on the health status of swine that was consistent with the previous results [3] [18]. Furthermore, it was demonstrated in this study that the addition of Sangrovit ${ }^{\circledast}$ to swine feed up to $1000 \mathrm{mg} / \mathrm{kg}$ does not result in any toxicological or adverse effects to the growth of piglets when fed for 90 days.

\section{Conclusion}

Based on the results in this study, the NOAEL (the no-observed-adverse-effect level) may be established at a concentration of $1000 \mathrm{mg} / \mathrm{kg}$ Sangrovit ${ }^{\oplus}$ in feed for swine, a concentration that is 10 fold of the recommended maximal concentration in feed.

\section{Acknowledgements}

The authors would like to thank Ms. Silvia Ulm for her help in formatting and editing the manuscript.

\section{Conflict of Interests}

The authors declare there is no conflict of interests.

\section{References}

[1] Vienna, C., Graz, R.B., Hohenheim, R.C., Milano, D.T., Trieste, A.T. and Wien K. (2007) Study on the Assessment of Plants/Herbs, Plant/Herb Extracts and their Naturally or Synthetically Produced Components as "Additives" for use in Animal Production CFT/EFSA/FEEDAP/2005/01. EFSA Supporting Publications, 4, 140 154. https://doi.org/10.2903/sp.efsa.2007.ZN-001

[2] Krane, B.D., Fagbule, M.O., Shamma, M. and Gozler, B. (1984) The Benzophenanthridine Alkaloids. Journal of Natural Products, 47, 1-43.

https://doi.org/10.1021/np50031a001

[3] Kantas, D., Papatsiros, V.G., Tassis, P.D., Athanasiou, L.V. and Tzika, E.D. (2015) The Effect of a Natural Feed Additive (Macleaya cordata), Containing Sanguinarine, on the Performance and Health Status of Weaning Pigs. Animal Science Journal, 86, 92-98. https://doi.org/10.1111/asj.12240

[4] Dvorák, Z. and Šmánek, V. (2007) Metabolism of Sanguinarine: The Facts and the 
Myths. Current Drug Metabolism, 8, 173-176.

https://doi.org/10.2174/138920007779815959

[5] Aguilar-Hernandez, J.A., Urias-Estrada, J.D., Lopez-Soto, M.A., Barreras, A., Plascencia, A., Montano, M., Gonzalez-Vizcarra, V.M., Estrada-Angulo, A., Castro-Perez, B.I., Barajas, R., Rogge, H.I. and Zinn, R.A. (2016) Evaluation of Isoquinoline Alkaloid Supplementation Levels on Ruminal Fermentation, Characteristics of Digestion, and Microbial Protein Synthesis in Steers Fed A High-Energy Diet. Journal of Animal Science, 94, 267-274. https://doi.org/10.2527/jas.2015-9376

[6] Vieira, S.L., Berres, J. and Reis, R.N. (2008) Studies with Sanguinarine like Alkaloids as Feed Additive in Broiler Diets. Revista Brasileira de Ciencia Avicola, 10, 67-71. https://doi.org/10.1590/S1516-635X2008000100010

[7] Rawling, M.D., Merrifield, D.L. and Davies, S.J. (2009) Preliminary Assessment of Dietary Supplementation of Sangrovit on Red Tilapia (Oreochromis niloticus) Growth Performance and Health. Aquaculture, 294, 118-122. https://doi.org/10.1016/j.aquaculture.2009.05.005

[8] Raloff, J. (2003) Food for Thought. Global Food Trends. https://www.sciencenews.org/blog/food-thought/global-food-trends

[9] da Silva, E.C., de Jager, N., Burgos-Paz, W., Reverter, A., Perez-Enciso, M. and Roura, E. (2014) Characterization of the Porcine Nutrient and Taste Receptor Gene Repertoire in Domestic and Wild Populations across the Globe. BMC Genomics, 15, 1-16. https://doi.org/10.1186/1471-2164-15-1057

[10] Chin, C.K. (2009) Plant Cell Culture as a Source of Valuable Chemicals. In: Havkin-Frenkel, D. and Belanger, F.C., Eds., Biotechnology in Flavor Production: A Case-Based Approach, Blackwell Publishing Ltd., 104-117.

[11] Yang, C., Chowdhury, M.A., Huo, Y. and Gong, J. (2015) Phytogenic Compounds as Alternatives to In-Feed Antibiotics: Potentials and Challenges in Application. Pathogens (Basel, Switzerland), 4, 137-156. https://doi.org/10.3390/pathogens4010137

[12] Matulka, R.A., von Alvensleben, S. and Morlacchini, M. (2014) Tolerance and Residue Study for Standardized Macleaya cordata Extract Added to Chicken Feed. International Journal of Poultry Science, 13, 368-373. https://doi.org/10.3923/ijps.2014.368.373

[13] Lee, K.W., Kim, J.S., Oh, S.T., Kang, C.W. and An, B.K. (2015) Effects of Dietary Sanguinarine on Growth Performance, Relative Organ Weight, Cecal Microflora, Serum Cholesterol Level and Meat Quality in Broiler Chickens. Journal of Poultry Science, 52, 15-22. https://doi.org/10.2141/jpsa.0140073

[14] Estrada-Angulo, A., Aguilar-Hernández, A., Osuna-Pérez, M., Núñez-Benítez, V.H., Castro-Pérez, B.I., Silva-Hidalgo, G., Contreras-Pérez, G., Barreras, A., Plascencia, A. and Zinn, R.A. (2016) Influence of Quaternary Benzophenantridine and Protopine Alkaloids on Growth Performance, Dietary Energy, Carcass Traits, Visceral Mass, and Rumen Health in Finishing Ewes under Conditions of Severe Temperature-Humidity Index. Asian-Australasian Journal of Animal Sciences, 29, 652-658. https://doi.org/10.5713/ajas.15.0300

[15] Artuso-Ponte, V., Moeller, S., Rajala-Schultz, P., Medardus, J.J., Munyalo, J., Lim, K. and Gebreyes, W.A. (2015) Supplementation with Quaternary Benzo(c)phenanthridine Alkaloids Decreased Salivary Cortisol and Salmonella Shedding in Pigs after Transportation to the Slaughterhouse. Foodborne Pathogens and Disease, 12, 891897. https://doi.org/10.1089/fpd.2015.2009

[16] Marquardt, R.R., Jin, L.Z., Kim, J.W., Fang, L., Frohlich, A.A. and Baidoo, S.K. (1999) Passive Protective Effect of Egg-Yolk Antibodies against Enterotoxigenic 
Escherichia coli K88+ Infection in Neonatal and Early-Weaned Piglets. FEMS Immunology and Medical Microbiology, 23, 283-288. https://doi.org/10.1111/j.1574-695X.1999.tb01249.x

[17] Rossi, L., Vagni, S., Polidori, C., Alborali, G., Baldi, A. and Dell'Orto, V. (2012) Experimental Induction of Escherichia coli Diarrhoea in Weaned Piglets. Open Journal of Veterinary Medicine, 2, 1-8. https://doi.org/10.4236/ojvm.2012.21001

[18] Kosina, P., Walterova, D., Ulrichova, J., Lichnovsky, V., Stiborova, M., Rydlova, H., Vicar, J., Krecman, V., Brabec, M.J. and Simanek, V. (2004) Sanguinarine and Chelerythrine: Assessment of Safety on Pigs in Ninety Days Feeding Experiment. Food and Chemical Toxicology, 42, 85-91. https://doi.org/10.1016/j.fct.2003.08.007

[19] Jeroch, H., Kozlowski, K., Jeroch, J., Lipinski, K., Zdunczyk, Z. and Jankowski, J. (2009) Efficacy of the Phytogenic (Papaveraceae) Additive Sangrovit in Growing Monogastric Animals. Zuchtungskunde, 81, 279-293.

[20] Velik-Salchner, C., Haas, T., Innerhofer, P., Streif, W., Nussbaumer, W., Klingler, A., Klima, G., Martinowitz, U. and Fries, D. (2007) The Effect of Fibrinogen Concentrate on Thrombocytopenia. Journal of Thrombosis and Haemostasis, 5, 10191025. https://doi.org/10.1111/j.1538-7836.2007.02481.x

[21] Pliszczak-Król, A., Rzasa, A., Gemra, M., Król, J., Luczak, G., Zyzak, A., Zalewski, D., Iwaszko-Simonik, A. and Graczyk, S. (2016) Age-Related Changes of Platelet and Plasma Coagulation Parameters in Young Pigs. Journal of Veterinary Diagnostic Investigation, 28, 561-567. https://doi.org/10.1177/1040638716658928

[22] Quaye, I.K. (2008) Haptoglobin, Inflammation and Disease. Transactions of the Royal Society of Tropical Medicine and Hygiene, 102, 735-742.

https://doi.org/10.1016/j.trstmh.2008.04.010

[23] Piñeiro, M., Piñeiro, C., Carpintero, R., Morales, J., Campbell, F.M., Eckersall, P.D., Toussaint, M.J.M. and Lampreave, F. (2007) Characterisation of the Pig Acute Phase Protein Response to Road Transport. Veterinary Journal, 173, 669-674. https://doi.org/10.1016/j.tvjl.2006.02.006

[24] Colombatti, R., De Bon, E., Bertomoro, A., Casonato, A., Pontara, E., Omenetto, E., Saggiorato, G., Steffan, A., Damian, T., Cella, G., Teso, S., Manara, R., Rampazzo, P., Meneghetti, G., Basso, G., Sartori, M.T. and Sainati, L. (2013) Coagulation Activation in Children with Sickle Cell Disease Is Associated with Cerebral Small Vessel Vasculopathy. PLoS ONE, 8, e78801. https://doi.org/10.1371/journal.pone.0078801

[25] Friendship, R.M., Lumsden, J.H., McMillan, I. and Wilson, M.R. (1984) Hematology and Biochemistry Reference Values for Ontario Swine. Canadian Journal of Comparative Medicine, 48, 390-393.

[26] Kim, D.H., Woo, J.H. and Lee, C.Y. (2004) Effects of Stocking Density and Transportation Time of Market Pigs on Their Behaviour, Plasma Concentrations of Glucose and Stress-Associated Enzymes and Carcass Quality. Asian-Australasian Journal of Animal Sciences, 17, 116-121. https://doi.org/10.5713/ajas.2004.116

[27] Nogueira, R.H.G., Guedes, R.M.C. and Souza, J.C.A. (2000) Serum Concentrations of Creatine Kinase and of Triglycerides during Lactation in Gilts Bred Older and in Multiparous Sows Fed Ad Libitum. Arquivo Brasileiro de Medicina Veterinaria e Zootecnia, 52, 65-67. https://doi.org/10.1590/S0102-09352000000100015

[28] Dubreuil, P. and Lapierre, H. (1997) Biochemistry Reference Values for Quebec Lactating Dairy Cows, Nursing Sows, Growing Pigs and Calves. Canadian Journal of Veterinary Research 61: 235-239.

[29] Yeom, S.C., Cho, S.Y., Park, C.G. and Lee, W.J. (2012) Analysis of Reference Interval and Age-Related Changes in Serum Biochemistry and Hematology in the Specific Pathogen Free Miniature Pig. Laboratory Animal Research, 28, 245-253. 
https://doi.org/10.5625/lar.2012.28.4.245

[30] Noblet, J. and Perez, J.M. (1993) Prediction of Digestibility of Nutrients and Energy Values of Pig Diets from Chemical Analysis. Journal of Animal Science, 71, 33893398.

[31] Noblet, J., Fortune, H., Shi, X.S. and Dubois, S. (1994) Prediction of Net Energy Value of Feeds for Growing Pigs. Journal of Animal Science, 72, 344-354.

Submit or recommend next manuscript to SCIRP and we will provide best service for you:

Accepting pre-submission inquiries through Email, Facebook, LinkedIn, Twitter, etc. A wide selection of journals (inclusive of 9 subjects, more than 200 journals)

Providing 24-hour high-quality service

User-friendly online submission system

Fair and swift peer-review system

Efficient typesetting and proofreading procedure

Display of the result of downloads and visits, as well as the number of cited articles Maximum dissemination of your research work

Submit your manuscript at: http://papersubmission.scirp.org/

Or contact ojas@scirp.org 